\title{
PREPARATION OF Fe-Pd BASED NANOPOROUS AMORPHOUS ALLOYS AND THEIR ELECTROCATALYTIC PROPERTIES DURING DECOMPOSITION OF FORMIC ACID
}

\author{
PRIPRAVA AMORFNIH NANOPOROZNIH ZLITIN NA OSNOVI \\ Fe-Pd IN NJIHOVE ELEKTROKATALITIČNE LASTNOSTI MED \\ RAZKRAJANJEM
}

\author{
Xue Li ${ }^{1}$, Jibo Zheng ${ }^{1}$, Gonghao Lu$^{2 *}$, Yu Liu ${ }^{1}$, Dechuan $\mathbf{Y u}^{1}$, Shengli Li ${ }^{1}$ \\ ${ }^{1}$ School of Materials and Metallurgy, University of Science and Technology, Liaoning, 185 Qianshan , Zhong Road, Anshan 114051, China \\ ${ }^{2}$ School of Chemical Engineering, University of Science and Technology Liaoning, 185 Qianshan Zhong Road, Anshan 114051, China
}

Prejem rokopisa - received: 2019-11-02; sprejem za objavo - accepted for publication: 2020-05-10

doi: $10.17222 /$ mit.2019.266

\begin{abstract}
In this study, Fe-Pd based amorphous alloys with a nanoporous structure were successfully prepared with dealloying treatment and their catalytic properties were investigated during the decomposition of formic acid ( $\mathrm{HCOOH})$. $\mathrm{Fe}_{60} \mathrm{Pd}_{20} \mathrm{P}_{20}$ amorphous-alloy ribbons with $1 \mathrm{~mm}$ in width and $25 \mu \mathrm{m}$ in thickness were prepared using vacuum melt-spinning. Then, nanoporous amorphous alloys with a three-dimensional uniform network structure were prepared with electrochemical dealloying in a sulfuric acid $\left(\mathrm{H}_{2} \mathrm{SO}_{4}\right)$ solution, using the $\mathrm{Fe}_{60} \mathrm{Pd}_{20} \mathrm{P}_{20}$ amorphous ribbons as the precursor alloy. Finally, the electrocatalytic properties of these nanoporous amorphous alloys were studied with cyclic voltammetry. In a mixed solution of $\mathrm{H}_{2} \mathrm{SO}_{4}(0.5 \mathrm{~mol} / \mathrm{L})$ and $\mathrm{HCOOH}(0.5 \mathrm{~mol} / \mathrm{L})$, the catalytic results showed that the nanoporous amorphous alloy dealloyed at a constant potential of $0.72 \mathrm{~V}$ exhibited an obviously negative shift of $0.35 \mathrm{~V}$ in the oxidation-peak potential of $\mathrm{HCOOH}$, while the oxidation-peak current density increased about 34 times. This means that the Fe-Pd based nanoporous amorphous alloy has an obvious catalytic effect on the decomposition of $\mathrm{HCOOH}$.

Keywords: nanoporous, amorphous alloy, dealloying, formic acid, electrocatalysis

Avtorji tega članka opisujejo uspešno pripravo nanoporoznih amorfnih zlitin na osnovi Fe-Pd s posebnim postopkom obdelave (razlegiranjem) in njihove katalitične lastnosti pri razkroju v mravljični kislini (HCOOH). Avtorji so pripravili amorfne trakove zlitine $\mathrm{Fe}_{60} \mathrm{Pd}_{20} \mathrm{P}_{20}$ široke $1 \mathrm{~mm}$ in $25 \mu \mathrm{m}$ debele trakove $\mathrm{s}$ postopkom nalivanja trakov na hitro vrtečem se valju v vakuumu (angl.: vacuum melt-spinning). $\mathrm{Z}$ elektrokemijskim razlegiranjem so nato v raztopini žveplene kisline, $\left(\mathrm{H}_{2} \mathrm{SO}_{4}\right)$, iz trakov izdelali amorfne tridimenzionalne strukture. Nazadnje so njihove elektrokatalitične lastnosti študirali s ciklično voltametrijo. V mešani raztopini $\mathrm{H}_{2} \mathrm{SO}_{4}(0.5 \mathrm{~mol} / \mathrm{L})$ in $\mathrm{HCOOH}(0.5 \mathrm{~mol} / \mathrm{L})$ so katalitični rezultati pokazali, da so nanoporozne amorfne zlitine razlegirane pri konstantnem potencialu $0,72 \mathrm{~V}$ in kažejo očiten premik maksimuma oksidacijskega potenciala $\mathrm{HCOOH}$ za 0,35 V. Oksidacijski maksimum tokovne gostote se je povečal za okoli 34-krat, kar pomeni, da ima izbrana Fe-Pd nanoporozna amorfna zlitina pomemben katalitični vpliv na razkroj $\mathrm{HCOOH}$.

Ključne besede: nanoporozne amorfne zlitine, razlegiranje, mravljična kislina, elektrokataliza
\end{abstract}

\section{INTRODUCTION}

Nanoporous metal materials have attracted much attention in recent years because of their high specific surface area and special interface characteristics. ${ }^{1}$ Therefore, they have been applied in many fields such as catalysis, ${ }^{2}$ sensors,${ }^{3}$ filters, ${ }^{4}$ optical detectors ${ }^{5}$ and supercapacitors. ${ }^{6}$ The preparation methods for nanoporous materials include the template method, ${ }^{7}$ dealloying method ${ }^{8}$ layer self-assembly technology 9 and so on. Among these preparation methods, the dealloying method utilizes the large difference in the electrode potential between the alloy components. The active components rapidly dissolve in the electrolyte, while the inert components diffuse and recombine to form a three-dimensional connective porous network structure. ${ }^{10,11}$ Compared with the other methods, the dealloying

*Corresponding author's e-mail: ghlu@ustl.edu.cn (Gonghao Lu) method has the advantages of a low cost, simple and efficient process and easy industrialization. Since J. Erlebacher et al. ${ }^{10}$ reported on a nanoporous metal structure with pore sizes of $2-50 \mathrm{~nm}$ obtained with the dealloying method in 2001 any nanoporous metal materials have been reported, including binary alloys of $\mathrm{Cu}-\mathrm{Pd},{ }^{12} \mathrm{Pd}-\mathrm{Au},{ }^{13} \mathrm{Cu}-\mathrm{Pt},{ }^{14} \mathrm{Ni}-\mathrm{Pt},{ }^{15} \mathrm{Ag}-\mathrm{Pd}{ }^{16}$ and $\mathrm{Ag}-\mathrm{Cu},{ }^{17}$ and ternary or multi-component alloys of $\mathrm{Ag}$-Au-Pt, ${ }^{18}$ Al-Pd-Au, ${ }^{19} \mathrm{Mg}-\mathrm{Ni}-\mathrm{Y}^{20}$ and Cu-based, ${ }^{21}$ Pt-based, ${ }^{22}$ Mg-based, ${ }^{23} \mathrm{Pd}$-based $^{24}$ and Al-based alloy systems. ${ }^{25}$ However, there are few reports on Fe-based ternary or multi-component nanoporous metal materials.

The key to the preparation of nanoporous metal materials by dealloying is the selection of suitable precursors. The precursor should have a homogeneous composition in the single-phase region. ${ }^{26}$ Amorphous alloys have feature structures of long-range disorder and short-range order, a homogeneous element composition, a wide range of the single-phase region and an active surface. There- 
fore, amorphous alloys are ideal precursors for nanoporous metal materials obtained by dealloying. They provide a new idea for preparing ternary or multi-component nanoporous materials by dealloying.

In this study, an $\mathrm{Fe}_{60} \mathrm{Pd}_{20} \mathrm{P}_{20}$ amorphous alloy was chosen as the precursor for dealloying. The effect of the constant potentials on the preparations of nanoporous amorphous alloys was first investigated. And then, the catalytic properties of these Fe-based nanoporous amorphous alloys with respect to formic acid $(\mathrm{HCOOH})$ were also further studied with the electrochemical method.

\section{MATERIALS AND METHODS}

\subsection{Materials}

$\mathrm{Fe}(99.9 w / \%), \mathrm{Pd}(99.9 w / \%)$ and the prealloyed ingot of $\mathrm{Fe}_{3} \mathrm{P}(99.5$ w/\%) were purchased from SigmaAldrich (China). Analytical-grade sulfuric acid $\left(\mathrm{H}_{2} \mathrm{SO}_{4}\right)$ and $\mathrm{HCOOH}$ were purchased from Sinopharm Chemical Reagent Co. Ltd.

\subsection{Methods}

$\mathrm{Fe}_{60} \mathrm{Pd}_{20} \mathrm{P}_{20}$ alloy ingots were prepared by vacuum induction melting under a high purified-argon atmosphere using the elements of high purity including $\mathrm{Fe}, \mathrm{Pd}$ and $\mathrm{Fe}_{3} \mathrm{P}$. The $\mathrm{Fe}_{60} \mathrm{Pd}_{20} \mathrm{P}_{20}$ amorphous-alloy ribbons with 1 $\mathrm{mm}$ in width and $25 \mu \mathrm{m}$ in thickness were prepared by melt-spinning. The structure of the amorphous ribbons was examined with X-ray diffraction (XRD, X'Pert Powder, PANalytical B.V. Company) with a $\mathrm{Cu}-K \alpha$ radiation. The morphologies of the amorphous ribbon and dealloying samples were observed with a field-emission scanning electron microscope (FESEM, ZEISS sigma 500, Carl Zeiss AG Company) and the compositions were determined with energy-dispersive spectrometer (EDS, QUANTAX, Bruker Corporation).

The electrochemical experiment and dealloying treatment were performed in a standard three-electrode cell with an electrochemical workstation (CHI660D, Shanghai Chenhua Device Company). The $\mathrm{Fe}_{60} \mathrm{Pd}_{20} \mathrm{P}_{20}$ amorphous alloy ribbon was used as the working electrode and an $\mathrm{Ag} / \mathrm{AgCl}$ electrode was used as the reference electrode with a platinum electrode as the counter electrode. The dealloying treatments at different constant potentials were carried out in an $\mathrm{H}_{2} \mathrm{SO}_{4}$ electrolyte $(1 \mathrm{~mol} / \mathrm{L})$ for $2 \mathrm{~h}$. The morphologies and compositions of the samples were observed with XRD, FESEM and EDS.

The prepared nanoporous sample was adhered to a glassy carbon electrode with a Nafion solution and this glassy carbon electrode was used as the working electrode. $\mathrm{Hg} / \mathrm{Hg}_{2} \mathrm{SO}_{4}$ was used as the reference electrode with a platinum wire as the counter electrode. Electrochemical activities were evaluated with a cyclic voltammetric curve obtained in the $\mathrm{H}_{2} \mathrm{SO}_{4}$ solution $(0.5 \mathrm{~mol} / \mathrm{L})$, while catalytic properties were evaluated with a cyclic voltammetric curve obtained in the mixed solution of $\mathrm{H}_{2} \mathrm{SO}_{4}(0.5 \mathrm{~mol} / \mathrm{L})$ and $\mathrm{HCOOH}(0.5 \mathrm{~mol} / \mathrm{L})$. The scanning rate was $50 \mathrm{mV} / \mathrm{s}$.

\section{RESULTS AND DISCUSSION \\ 3.1 Alloy design and amorphous characteristic}

In order to obtain homogeneous nanoporous materials, the amorphous alloy precursor should meet the requirements of the dealloying method as well as Inoue's principles for the preparation of amorphous alloys. ${ }^{26,27}$ The dealloying requirements include four points: 1) the alloy should have a wide single-phase region; 2) the electrode potential differences between the alloying elements should be large enough; 3 ) the highly active element should be the main component of the alloy; and 4) the diffusion rate of the inert elements at the interface of the alloy and electrolyte should be fast enough. The mixing enthalpies of the three elements in the $\mathrm{Fe}_{60} \mathrm{Pd}_{20} \mathrm{P}_{20}$ alloy are $-4 \mathrm{KJ} / \mathrm{mol}$ for $\mathrm{Fe}-\mathrm{Pd},-36.5 \mathrm{KJ} / \mathrm{mol}$ for Pd-P and $-39.5 \mathrm{KJ} / \mathrm{mol}$ for Fe-P, respectively, ${ }^{28}$ and all the values are negative. In addition, the atomic radiuses are 0.1241 $\mathrm{nm}$ for Fe, $0.1376 \mathrm{~nm}$ for Pd and $0.1000 \mathrm{~nm}$ for P. All the ratios of atomic radiuses are more than $12 \%$, meeting Inoue's principles. These data ensure that a uniform amorphous state is easily obtained in the $\mathrm{Fe}_{60} \mathrm{Pd}_{20} \mathrm{P}_{20}$ alloy.

On the other hand, the standard reduction potentials are $-0.440 \mathrm{~V}$ for $\mathrm{Fe}$ and $0.987 \mathrm{~V}$ for $\mathrm{Pd}$, with the standard hydrogen electrode as the reference electrode. ${ }^{29}$ The potential difference between $\mathrm{Fe}$ and $\mathrm{Pd}$ is large enough. Moreover, the Fe element is easy to corrode and dissolve in an acid solution, and Pd easily diffuses and recombines to form a three-dimensional connective porous network structure. ${ }^{26,30}$ And then, the addition of the P element can promote the formation of the nanoporous structure and enhance the catalytic property and stability of the nanoporous material. ${ }^{31}$ Finally, from an economic point of view, the active Fe element is cheap and easy to get, and $\mathrm{Pd}$ is a relatively cheap precious metal as its price is only half of the price for gold. Because of the

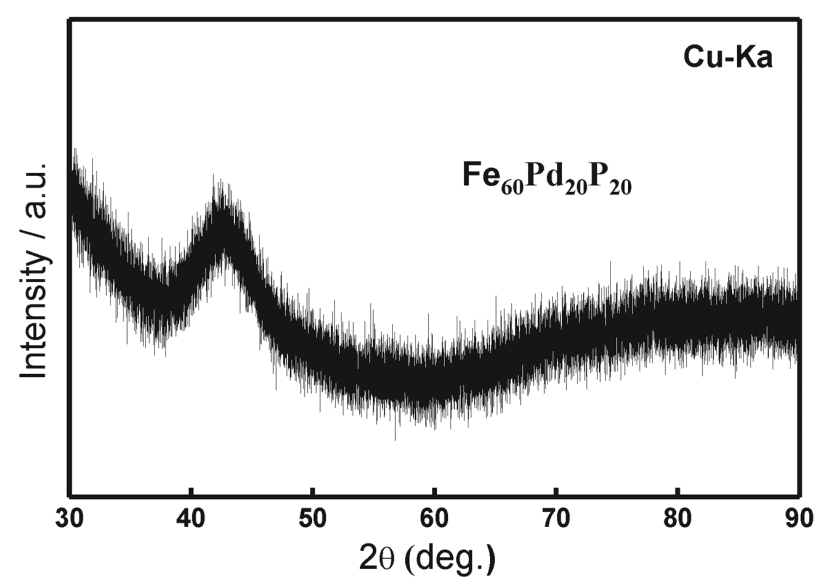

Figure 1: XRD pattern of $\mathrm{Fe}_{60} \mathrm{Pd}_{20} \mathrm{P}_{20}$ amorphous-alloy ribbon 
above good features, the $\mathrm{Fe}_{60} \mathrm{Pd}_{20} \mathrm{P}_{20}$ amorphous alloy was designed as the precursor alloy in this study.

The XRD pattern of the $\mathrm{Fe}_{60} \mathrm{Pd}_{20} \mathrm{P}_{20}$ amorphous-alloy ribbon is shown in Figure 1. The XRD pattern shows a broad peak around $2 \theta=40-48^{\circ}$ and no distinguishable diffraction peaks of crystalline phases, which indicates that the prepared $\mathrm{Fe}_{60} \mathrm{Pd}_{20} \mathrm{P}_{20}$ alloy ribbon is amorphous.

\subsection{Analysis of the electrochemical property of the amorphous alloy}

Figure 2 shows a dynamic-potential polarization curve of $\mathrm{Fe}_{60} \mathrm{Pd}_{20} \mathrm{P}_{20}$ in $1 \mathrm{~mol} / \mathrm{L} \mathrm{H}_{2} \mathrm{SO}_{4}$ electrolyte exposed to air at $298 \mathrm{~K}$. The interval form I to II on the polarization curve is the electro-dissolution range. The current density increases rapidly to reach the maximum with the positive shift of the metal electrode potential and the active metal element dissolves, as shown with the equation $\mathrm{Fe} \rightarrow \mathrm{Fe}^{2+}+2 \mathrm{e}^{-}$. When the potential exceeds point II, the metal electrode material is partially electrochemically passivated, which reduces the dissolution rate. Thus, the current density rapidly drops from the highest value to point III, and the interval from II to III is the electrode transition zone. When the potential exceeds point III, the metal electrode is in a stable state and the current density hardly changes with the voltage. Therefore, the polarization curve is almost a straight horizontal line and the interval from III to IV is a stable zone.

In the study, the constant potentials of $0.72 \mathrm{~V}$ (dissolution zone), $0.77 \mathrm{~V}$ (transition zone) and $0.97 \mathrm{~V}$ (stability zone) were selected for dealloying experiments. The effect of the constant potentials on the preparation of the Fe-Pd based nanoporous amorphous alloys was investigated. Figure 3 shows the changes in the current densities of the $\mathrm{Fe}_{60} \mathrm{Pd}_{20} \mathrm{P}_{20}$ amorphous ribbons with the dealloying times. When the constant potential is $0.72 \mathrm{~V}$, the electrochemical reaction on the metal electrode is $\mathrm{Fe} \rightarrow \mathrm{Fe}^{2+}+2 \mathrm{e}^{-32}$ and the current density increases with the dealloying time. When the constant potential is 0.77 $\mathrm{V}$, the current density increases slowly with the dealloying time, and the current density is lower than

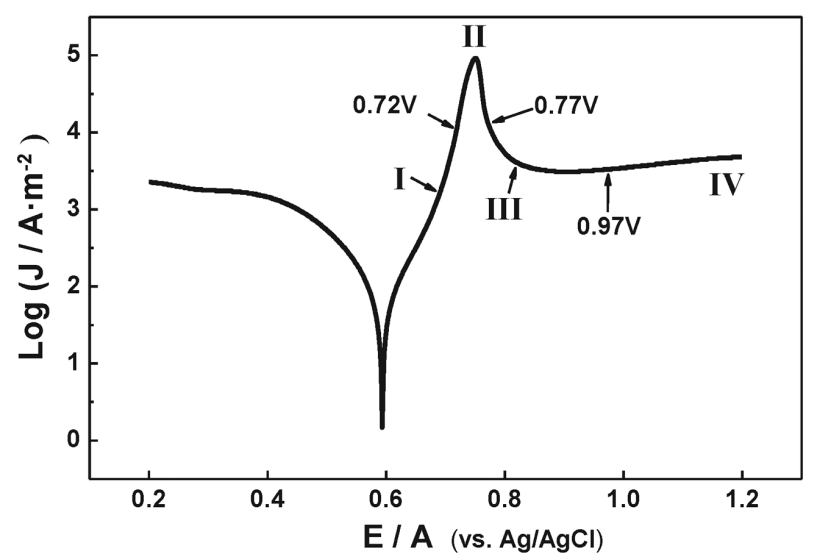

Figure 2: Polarization curve of $\mathrm{Fe}_{60} \mathrm{Pd}_{20} \mathrm{P}_{20}$ amorphous-alloy ribbon in $1 \mathrm{~mol} / \mathrm{L} \mathrm{H}_{2} \mathrm{SO}_{4}$ solution at $25{ }^{\circ} \mathrm{C}$ that of the constant potential of $0.72 \mathrm{~V}$. When the constant potential is $0.97 \mathrm{~V}$ in the stable zone of the metal electrode, the current density remains relatively stable after a period of dealloying of 15 minutes.

\subsection{Effect of dealloying constant potentials on nano- porous structures}

In order to confirm the effect of dealloying constant potentials on the nanoporous structures of the prepared samples, the sample morphologies were observed with FESEM (Figure 4). Figure 4a shows the SEM morphology of an original $\mathrm{Fe}_{60} \mathrm{Pd}_{20} \mathrm{P}_{20}$ amorphous alloy ribbon (as-quenched). No crystalline phase was observed on the surface of the sample, which is consistent with the XRD result. Figure $\mathbf{4 b}$ shows the morphology of the sample prepared by dealloying at a constant potential of $0.72 \mathrm{~V}$ for $2 \mathrm{~h}$ (NP-Pd1). A large number of pores with diameters of 10-25 nm appeared on the surface of the sample and nanoporous structures were observed. When the dealloying constant potential was $0.72 \mathrm{~V}$ in the dissolution zone of the polarization curve, the corrosion rate of Fe was greatly increased. The EDS results showed that the Fe content in the sample significantly decreased to $42.05 \%$ (Table 1), indicating that Fe was corroded and dissolved in the electrolyte $\left(\mathrm{Fe} \rightarrow \mathrm{Fe}^{2+}+2 \mathrm{e}^{-}\right)$. In the process of $\mathrm{Fe}$ corrosion, $\mathrm{Pd}$ diffused and recombined to form a nanoporous structure. However, as the ligament was relatively thick, no three-dimensionally connected pore structure was formed.

Figure 4c shows the morphology of the sample prepared by dealloying at a constant potential of $0.77 \mathrm{~V}$ for $2 \mathrm{~h}$ (NP-Pd2). A lot of pores with diameters of 50-90 nm appeared on the surface of the sample. The EDS results showed that the content of $\mathrm{Fe}$ was reduced because $\mathrm{Fe}$ in the sample was corroded and dissolved in the electrolyte (Table 1). Compared with the sample prepared at the constant potential of $0.72 \mathrm{~V}$, the $\mathrm{Fe}$ and $\mathrm{Pd}$ content changed less because the dealloying constant potential

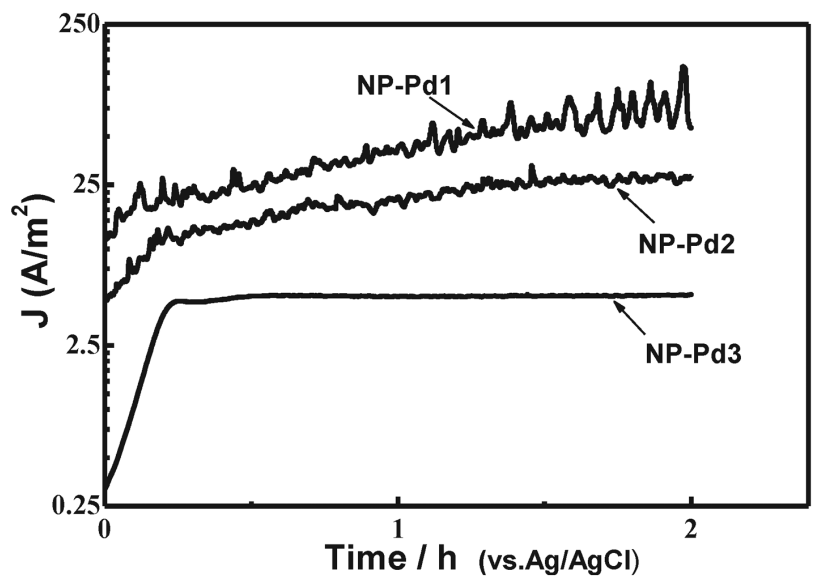

Figure 3: Changes of the current densities of the $\mathrm{Fe}_{60} \mathrm{Pd}_{20} \mathrm{P}_{20}$ amorphous ribbons with the dealloying times in $1 \mathrm{~mol} / \mathrm{L} \mathrm{H}_{2} \mathrm{SO}_{4}$ solution at $25{ }^{\circ} \mathrm{C}$ 

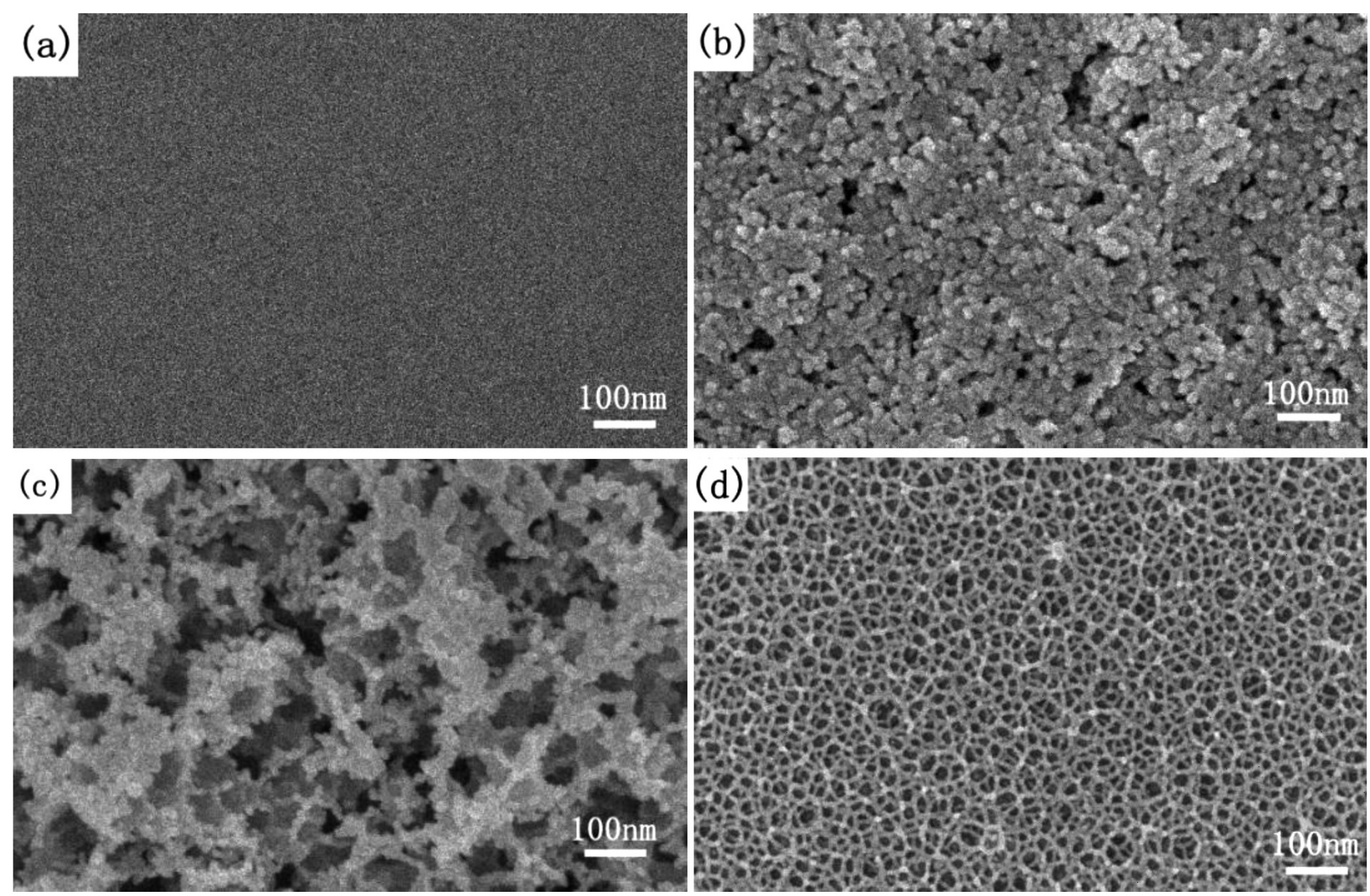

Figure 4: SEM images of $\mathrm{Fe}_{60} \mathrm{Pd}_{20} \mathrm{P}_{20}$ alloy and samples after potentiostatic dealloying in $0.5 \mathrm{~mol} / \mathrm{L} \mathrm{H}_{2} \mathrm{SO}_{4}$ solution at $25{ }^{\circ} \mathrm{C}$ : a) as-quenched, b) NP-Pd1, c) NP-Pd2, d) NP-Pd3

was $0.77 \mathrm{~V}$ in the transition region of the polarization curve. Parts of the reaction should thus be $\mathrm{Fe}+\mathrm{H}_{2} \mathrm{O} \rightarrow$ $(\mathrm{FeOH})_{\mathrm{ad}}+\mathrm{H}^{+}+\mathrm{e}^{-}$and $(\mathrm{FeOH})_{\mathrm{ad}}+\mathrm{H}_{2} \mathrm{O} \rightarrow\left[\mathrm{Fe}(\mathrm{OH})_{2}\right]_{\mathrm{ad}}+$ $\mathrm{H}^{+}+\mathrm{e}^{-.32}\left[\mathrm{Fe}(\mathrm{OH})_{2}\right]_{\mathrm{ad}}$. The formation from the corrosion reaction adheres to the surface of the sample, thus limiting further corrosion. Therefore, it is possible to form uniform nanoporous structures.

Table 1: EDS analysis results for different nanoporous alloys

\begin{tabular}{|c|c|c|c|}
\hline \multirow{2}{*}{$\begin{array}{c}\text { Nanoporous } \\
\text { alloy }\end{array}$} & \multicolumn{3}{|c|}{ Element content $(a / \%)$} \\
\cline { 2 - 4 } & $\mathrm{Fe}$ & $\mathrm{Pd}$ & $\mathrm{P}$ \\
\hline NP-Pd1 & 42.05 & 42.32 & 15.63 \\
\hline NP-Pd2 & 53.77 & 25.80 & 20.43 \\
\hline NP-Pd3 & 55.72 & 23.31 & 20.97 \\
\hline
\end{tabular}

Figure 4d shows the morphology of the sample prepared by dealloying at a constant potential of $0.97 \mathrm{~V}$ for $2 \mathrm{~h}$ (NP-Pd3). A lot of pores with diameters of 30-50 nm appeared on the surface of the sample and a three-dimensional porous network structure was observed. The size of the ligament was about $10 \mathrm{~nm}$. The EDS results for each elements showed that the changes were small (Table 1) as the dealloying constant potential was $0.97 \mathrm{~V}$ in the stable region of the polarization curve. The dealloying rate was low enough, resulting in the formation of three-dimensional uniform nanoporous structures. In a word, using an $\mathrm{Fe}_{60} \mathrm{Pd}_{20} \mathrm{P}_{20}$ amorphous alloy ribbon as the precursor, nanoporous amorphous alloys with a three-dimensional uniform network structure can be prepared by electrochemical dealloying. Meanwhile, the constant potentials of the dealloying process have an important influence on the compositions and morphologies of the nanoporous amorphous alloys.

\subsection{Electrochemical activities of nanoporous amor- phous alloys}

Figure 5 shows cyclic voltammetric curves of the alloy samples from $0.5 \mathrm{~mol} / \mathrm{L} \mathrm{H}_{2} \mathrm{SO}_{4}$ solution. The curves clearly reflect the hydrogen-evolution and oxygen-evolution processes of the electrodes as well as the adsorption and desorption behaviours of hydrogen and oxygen. Hc is the reduction peak of hydrogen, while $\mathrm{Ha}$ is the oxidation peak of hydrogen. Based on the adsorption/desorption peak area of hydrogen, the electrochemical active surface area (ECSA) was obtained. The larger the electrochemical active surface area, the better is the catalytic activity of the amorphous alloy. ${ }^{33}$ As shown in Figure 5, the redox peak of the as-quenched sample was very small. The NP-Pd1 sample showed the largest adsorption/desorption peak, and the NP-Pd2 sample showed the second largest adsorption/desorption peak, while sample NP-Pd3 showed a small adsorption/desorption peak, close to that of the original amorphous-alloy ribbon. The ECSAs (in Figure 6) of the samples were calculated with Equation (1). ${ }^{34,35}$ The ECSA value of the 


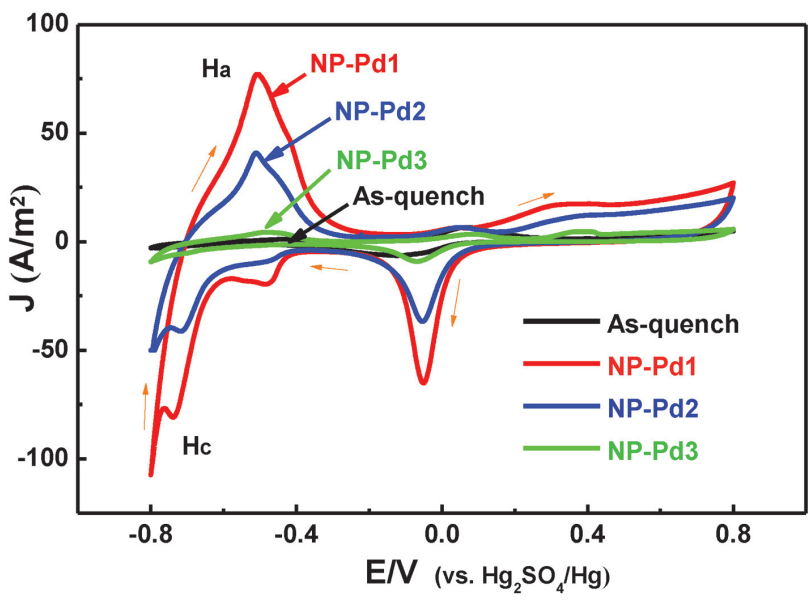

Figure 5: $\mathrm{CV}$ curves of $\mathrm{Fe}_{60} \mathrm{Pd}_{20} \mathrm{P}_{20}$ alloy and nanoporous alloy in $0.5 \mathrm{~mol} / \mathrm{L} \mathrm{H}_{2} \mathrm{SO}_{4}$ solution

as-quenched sample was $0.31 \times 10^{-3} \mathrm{~cm}^{2} / \mathrm{g}$ and the ECSA values of samples NP-Pd1, NP-Pd2 and NP-Pd3 were 90,22 and 5 times larger than that of the as-quenched sample, respectively. These results indicate that the ECSA values of the nanoporous amorphous alloys were increased and the NP-Pd1 sample had the maximum ECSA value.

$$
\begin{aligned}
& \operatorname{ECSA}\left(\mathrm{cm}^{2} / \mathrm{g}\right)= \\
& =\frac{\text { Charge }\left(\mathrm{mC} / \mathrm{cm}^{2}\right)}{\text { Catalyst loading }\left(\mathrm{g} / \mathrm{cm}^{2}\right) \times 210\left(\mathrm{mC} / \mathrm{cm}^{2}\right)}
\end{aligned}
$$

The charge is the total amount of the catalyst surface charge obtained by integrating the adsorption/desorption peak areas of hydrogen on the CV curve.

\subsection{Electrocatalytic properties of nanoporous amor- phous alloys for the decomposition of $\mathrm{HCOOH}$}

Figure 7 shows the cyclic voltammetric curves of the alloy samples in $0.5 \mathrm{~mol} / \mathrm{L} \mathrm{H}_{2} \mathrm{SO}_{4}+0.5 \mathrm{~mol} / \mathrm{L} \mathrm{HCOOH}$. The results showed the nanoporous samples exhibited oxidation peaks in the positive and negative sweeps of

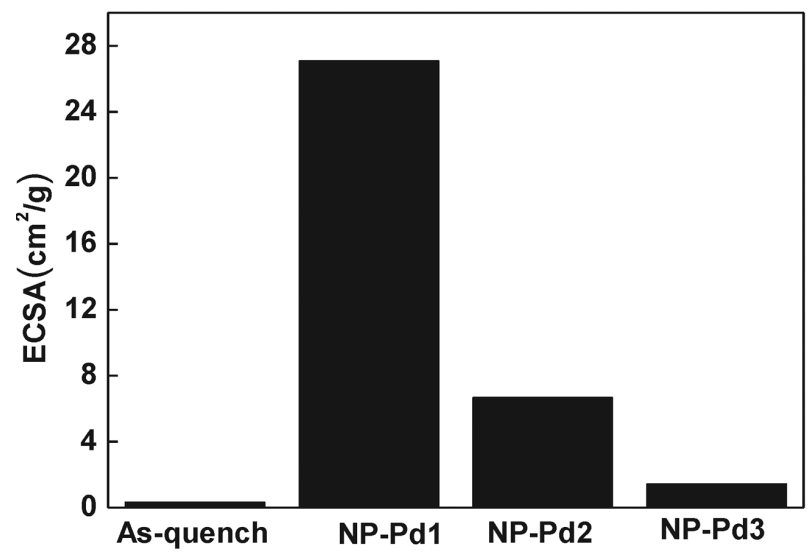

Figure 6: ECSA values of nanoporous alloy and as-quenched sample in $0.5 \mathrm{~mol} / \mathrm{L} \mathrm{H}_{2} \mathrm{SO}_{4}$ solution
$\mathrm{HCOOH}$. In the positive sweep of $\mathrm{HCOOH}, \mathrm{CO}_{2}$ formed during the oxidation reaction. The reaction equation was $\mathrm{HCOOH} \rightarrow \mathrm{CO}_{2}+2 \mathrm{H}^{+}+2 \mathrm{e}^{-} \cdot 36,37$ and the adsorption of $\mathrm{CO}_{2}$ was very weak on the surface of $\mathrm{Pd}$. According to the potentials and current densities of the oxidation peaks for different alloy samples, we can determine the electrocatalytic properties of nanoporous amorphous alloys. ${ }^{38}$ The potentials and current densities of the oxidation peaks were $0.15 \mathrm{~V}$ and $4.5 \mathrm{~A} / \mathrm{m}^{2}$ for the as-quenched sample, $-0.2 \mathrm{~V}$ and $155 \mathrm{~A} / \mathrm{m}^{2}$ for NP-Pd1, $-0.2 \mathrm{~V}$ and $115 \mathrm{~A} / \mathrm{m}^{2}$ for NP-Pd2 and $-0.2 \mathrm{~V}$ and $14 \mathrm{~A} / \mathrm{m}^{2}$ for NP-Pd3 (Figure 7).

Compared with the as-quenched sample, the potential of NP-Pd1 was negatively shifted by $0.35 \mathrm{~V}$ and the current density of NP-Pd1 was enhanced 34 times, the potential of NP-Pd2 was negatively shifted by $0.35 \mathrm{~V}$ and the current density of NP-Pd2 was enhanced 26 times, and the potential of NP-Pd3 was negatively shifted by $0.40 \mathrm{~V}$ and the current density of NP-Pd3 was enhanced 3 times. Anyway, compared with the $\mathrm{Fe}_{60} \mathrm{Pd}_{20} \mathrm{P}_{20}$ amorphous ribbon, the potentials of the oxidation peaks for the nanoporous samples were negatively shifted by $0.35-0.4 \mathrm{~V}$ and all the current densities of the oxidation peaks were obviously improved. Therefore, the prepared nanoporous amorphous alloys showed catalytic properties on the decomposition of $\mathrm{HCOOH}$.

In the dealloying process, the Fe element corroded and dissolved, while the Pd element diffused and recombined to form nanoporous structures. As a result, the active surface areas were significantly enlarged. Fe atoms can affect the electron structure on $d$ orbital of Pd atoms due to a stress-induction effect, ${ }^{39}$ thus increasing the catalytic activities of Pd. In addition, Pd atoms have a special affinity with hydrogen, ${ }^{40}$ which causes the $\mathrm{HCOOH}$ molecules to be quickly dehydrogenated on the surface of $\mathrm{Pd}$, and the reaction formula is $\mathrm{HCOOH}_{\mathrm{ad}} \rightarrow \mathrm{CO}_{2}+$ $2 \mathrm{H}^{+}+2 \mathrm{e}^{-}$. Pd absorbs the reactants to activate the molecules by chemical adsorption bonding. Therefore, the activation energy of the reaction is reduced and thus the catalytic reaction rate of $\mathrm{HCOOH}$ is increased. Sample

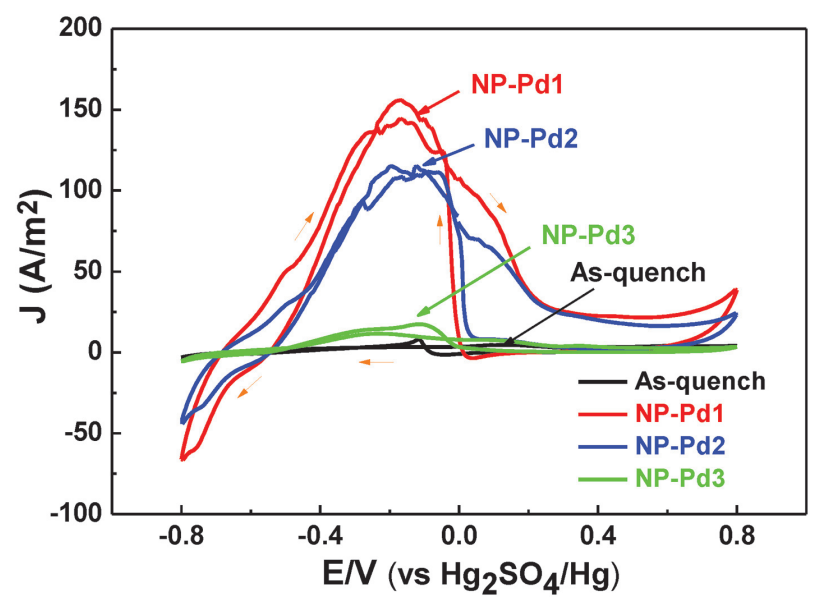

Figure 7: $\mathrm{CV}$ curves of alloy samples in $0.5 \mathrm{~mol} / \mathrm{L} \mathrm{H}_{2} \mathrm{SO}_{4}$ and $0.5 \mathrm{~mol} / \mathrm{L} \mathrm{HCOOH}$ solution at $25^{\circ} \mathrm{C}$ 
NP-Pd1 has the highest Pd atomic content (42.32\%), which greatly improves the catalytic effect of sample $\mathrm{NP}-\mathrm{Pd} 1$ on $\mathrm{HCOOH}$. In contrast to the $\mathrm{Fe}_{60} \mathrm{Pd}_{20} \mathrm{P}_{20}$ amorphous-alloy ribbon, all the nanoporous amorphous alloys showed improvements in the catalytic properties on the decomposition of $\mathrm{HCOOH}$.

\section{CONCLUSIONS}

In summary, $\mathrm{Fe}_{60} \mathrm{Pd}_{20} \mathrm{P}_{20}$ amorphous-alloy ribbons with $1 \mathrm{~mm}$ in width and $25 \mu \mathrm{m}$ in thickness were prepared with vacuum induction melting and vacuum melt-spinning. The dealloying constant potentials have an important influence on the morphologies of nanoporous amorphous alloys. Three-dimensional nanoporous amorphous alloys with diameters of 20-40 nm were prepared by dealloying at a constant potential of $0.72 \mathrm{~V}$ for $2 \mathrm{~h}$ in $1 \mathrm{~mol} / \mathrm{L} \mathrm{H}_{2} \mathrm{SO}_{4}$ solution using the $\mathrm{Fe}_{60} \mathrm{Pd}_{20} \mathrm{P}_{20}$ amorphous ribbons as the precursor alloy. The nanoporous amorphous alloys had more surface active area and their electrocatalytic properties for $\mathrm{HCOOH}$ were enhanced. The nanoporous amorphous alloy obtained at $0.72 \mathrm{~V}$ (NP-Pd1) exhibited the maximum surface active area and the best electrocatalytic effect among all the alloys. In the decomposition of $\mathrm{HCOOH}$, compared with the $\mathrm{Fe}_{60} \mathrm{Pd}_{20} \mathrm{P}_{20}$ amorphous ribbon, all the nanoporous amorphous alloys showed an increase in the catalytic properties. Among them, NP-Pd1 showed the best performance. The oxidation-peak potential was negatively shifted by $0.35 \mathrm{~V}$ and the oxidation-peak current density increased about 34 times in $0.5 \mathrm{~mol} / \mathrm{L} \mathrm{H}_{2} \mathrm{SO}_{4}+$ $0.5 \mathrm{~mol} / \mathrm{L} \mathrm{HCOOH}$ solution.

\section{Acknowledgment}

This work was sponsored by the National Natural Science Foundation of China (Grant No. 51501084), Natural Science Foundation of the Liaoning Province (Grant No. 201602398) and Foundation of the University of Science and Technology Liaoning (Grant No. 2015RC01).

\section{REFERENCES}

${ }^{1}$ F. L. Jia, C. F. Yu, K. J. Deng, L. Z. Zhang, Nanoporous Metal $(\mathrm{Cu}$, $\mathrm{Ag}, \mathrm{Au})$ Films with High Surface Area: General Fabrication and Preliminary Electrochemical Performance, J. Phys. Chem. C, 111 (2007), 8424-8431, doi:10.1021/jp071815y

${ }^{2}$ H. J. Qiu, X. R. Huang, Effects of Pt decoration on the electrocatalytic activity of nanoporous gold electrode toward glucose and its potential application for constructing a nonenzymatic glucose sensor, J. Electroanal. Chem., 643 (2010), 39-45, doi:10.1016/ j.jelechem.2010.03.011

${ }^{3}$ S. Kavian, S. N. Azizi, S. Ghasemi, Novel bimetallic nanoporous Pd-Cu-SBA-16/CPE as a highly sensitive sensor for determination of formaldehyde, J. Electroanal. Chem., 799 (2017), 308-314, doi:10.1016/j.jelechem.2017.06.006

${ }^{4}$ W. F. Li, Y. M. Yang, J. K. Weber, G. Zhang, R. H. Zhou, Tunable, strain-controlled nanoporous $\mathrm{MoS}_{2}$ filter for water desalination, ACS Nano, 10 (2016), 1829-1835, doi:10.1021/acsnano.5b05250
${ }^{5}$ R. Ron, E. Haleva, A. Salomon, Nanoporous metallic networks: fabrication, optical properties, and applications, Adv. Mater., 30 (2018), 1706755, doi:10.1002/adma.201706755

${ }^{6}$ R. R. Salunkhe, Y. V. Kaneti, Y. Yamauchi, Metal-organic framework-derived nanoporous metal oxides toward supercapacitor applications: progress and prospects, ACS Nano, 11 (2017), 5293-5308, doi:10.1021/acsnano.7b02796

${ }^{7}$ J. C. Hulteen, C. R. Martin, A general template-based method for the preparation of nanomaterials, J. Mater. Chem., 7 (1997), 1075-1087, doi:10.1039/A700027H

${ }^{8}$ Z. H. Zhang, Y. Wang, Z. Qi, W. H. Zhang, J. Y. Qin, J. Frenzel, Generalized fabrication of nanoporous metals (Au, Pd, Pt, Ag, and $\mathrm{Cu}$ ) through chemical dealloying, J. Phys. Chem. C, 113 (2009), 12629-12636, doi:10.1021/jp811445a

${ }^{9}$ Y. Xiang, S. Lu, S. P. Jiang, Layer-by-layer self-assembly in the development of electrochemical energy conversion and storage devices from fuel cells to supercapacitors, Chem. Soc. Rev., 41 (2012), 7291-7321, doi:10.1039/C2CS35048C

${ }^{10}$ J. Erlebacher, M. J. Aziz, A. Karma, N. Dimitrov, K. Sieradzki, Evolution of nanoporosity in dealloying, Nature, 410 (2001), 450-453, doi:10.1038/35068529

${ }^{11}$ H. J. Qiu, L. Peng, X. Li, H. T. Xu, Y. Wang, Using corrosion to fabricate various nanoporous metal structures, Corros. Sci., 92 (2015), 16-31, doi:10.1016/j.corsci.2014.12.017

${ }^{12}$ Z. H. Zhang, C. Zhang, J. Z. Sun, T. Y. Kou, C. C. Zhao, Ultrafine nanoporous $\mathrm{Cu}-\mathrm{Pd}$ alloys with superior catalytic activities towards electro-oxidation of methanol and ethanol in alkaline media, RSC Adv., 2 (2012), 11820-11828, doi:10.1039/C2RA21905K

${ }^{13}$ X. G. Wang, B. Tang, X. B. Huang, Y. Ma, Z. H. Zhang, High activity of novel nanoporous $\mathrm{Pd}-\mathrm{Au}$ catalyst for methanol electro-oxidation in alkaline media, J. Alloys Compd., 565 (2013), 120-126, doi:10.1016/j.jallcom.2013.02.170

${ }^{14}$ H. J. Qiu, X. Shen, J. Q. Wang, A. Hirata, T. Fujita, Y. Wang, M. W. Chen, Aligned nanoporous $\mathrm{Pt}-\mathrm{Cu}$ bimetallic microwires with high catalytic activity toward methanol electrooxidation, ACS Catal., 5 (2015), 3779-3785, doi:10.1021/acscatal.5b00073

${ }^{15}$ H. Li, A. Misra, J. K. Baldwin, S.T. Picraux, Synthesis and characterization of nanoporous Pt-Ni alloys, Appl. Phys. Lett., 95 (2009), 201902, doi:10.1063/1.3265744

${ }^{16}$ H. J. Qiu, Z. H. Zhang, X. R. Huang, Y. B. Qu, Dealloying Ag-Al alloy to prepare nanoporous silver as a substrate for surface-enhanced raman scattering: effects of structural evolution and surface modification, ChemPhysChem, 12 (2011), 2118-2123, doi:10.1002/ cphc. 201100205

${ }^{17}$ R. Li, N. Wu, J. J. Liu, Y. Jin, X. B. Chen, T. Zhang, Formation and evolution of nanoporous bimetallic Ag-Cu alloy by electrochemically dealloying Mg-(Ag-Cu)-Y metallic glass, Corros. Sci., 119 (2017), 23-32, doi:10.1016/j.corsci.2017.02.017

${ }^{18}$ A. A. Vega, R. C. Newman, Nanoporous Metals Fabricated through Electrochemical Dealloying of Ag-Au-Pt with Systematic Variation of Au:Pt Ratio, J. Electrochem. Soc., 161 (2014), C1-C10, doi:10.1149/2.003401jes

${ }^{19}$ X. G. Wang, J. Z. Sun, C. Zhang, T. Y. Kou, Z. G. Zhang, On the microstructure, chemical composition, and porosity evolution of nanoporous alloy through successive dealloying of ternary Al-Pd-Au precursor, J. Phys. Chem. C, 116 (2012), 13271-13280, doi:10.1021/jp3035677

${ }^{20}$ L. Zuo, R. Li, Y. Jin, H. J. Xu, T. Zhang, Fabrication of three-dimensional nanoporous nickel by dealloying $\mathrm{Mg}-\mathrm{Ni}-\mathrm{Y}$ metallic glasses in citric acid solutions for high-performance energy storage, J. Electrochem. Soc., 164 (2017), A348-A354, doi:10.1149/ 2.1131702jes

${ }^{21}$ Z. F. Wang, J. Y. Liu, C. L. Qin, H. Yu, X. C. Xia, C. Y. Wang, Y. S. Zhang, Q. F. Hu, W. M. Zhao, Dealloying of Cu-based metallic glasses in acidic solutions: products and energy storage applications, Nanomaterials, 5 (2015), 697-721, doi:10.3390/nano5020697 
${ }^{22} \mathrm{Y} . \mathrm{Xu}, \mathrm{B}$. Zhang, Recent advances in porous Pt-based nanostructures: synthesis and electrochemical applications, Chem. Soc. Rev., 43 (2014), 2439-2450, doi:10.1039/C3CS60351B

${ }^{23}$ X. K. Luo, R. Li, L. Huang, T. Zhang, Nucleation and growth of nanoporous copper ligaments during electrochemical dealloying of Mg-based metallic glasses, Corros. Sci., 67 (2013), 100-108, doi:10.1016/j.corsci.2012.10.010

${ }^{24}$ C. L. Yang, X. H. Zhang, G. Lan, L. Y. Chen, M. W. Chen, Y. Q. Zeng, J. Q. Jiang, Pd-based nanoporous metals for enzyme-free electrochemical glucose sensors, Chin. Chem. Lett., 25 (2014), 496-500, doi:10.1016/j.cclet.2014.02.001

${ }^{25}$ Q. Zhang, Z. H. Zhang, On the electrochemical dealloying of Al-based alloys in a $\mathrm{NaCl}$ aqueous solution, Phys. Chem. Chem. Phys. 12 (2010), 1453-1472, doi:10.1039/B919313H

${ }^{26} \mathrm{~J}$. Erlebacher, An atomistic description of dealloying porosity evolution, the critical potential, and rate-limiting behavior, J. Electrochem. Soc., 10 (2004), C614-C626, doi:10.1149/1.1784820

${ }^{27}$ A. Takeuchi, A. Inoue, Calculations of amorphous-forming composition range for ternary alloy systems and analyses of stabilization of amorphous phase and amorphous-forming ability, Mater. Trans., 42 (2001), 1435-1444, doi:10.2320/matertrans.42.1435

${ }^{28}$ A. Takeuchi, A. Inoue, Classification of bulk metallic glasses by atomic size difference, heat of mixing and period of constituent elements and its application to characterization of the main alloying element, Mater. Trans., 46 (2005), 2817-2829, doi:10.2320/matertrans. 46.2817

${ }^{29}$ M. Hakamada, M. Mabuchi, Preparation of nanoporous palladium by dealloying: anodic polarization behaviors of $\mathrm{Pd}-\mathrm{M}(\mathrm{M}=\mathrm{Fe}, \mathrm{Co}, \mathrm{Ni})$ alloys, Mater. Trans., 50 (2009), 431-435, doi:10.2320/matertrans. MBW200825

${ }^{30}$ M. Hakamada, K. Tajima, K. Yoshimura, Y. Chino, M. Mabuchi, Solid/electrolyte interface phenomena during anodic polarization of $\mathrm{Pd}_{0.2} \mathrm{M}_{0.8}(\mathrm{M}=\mathrm{Fe}, \mathrm{Co}, \mathrm{Ni})$ alloys in $\mathrm{H}_{2} \mathrm{SO}_{4}$, J. Alloys Compd., 494 (2010), 309-314, doi:10.1016/j.jallcom.2010.01.019

${ }^{31}$ J. S Yu, Y. Ding, C. X. Xu, A. Inoue, T. Sakurai, T. Sakurai, M. Chen, Nanoporous metals by dealloying multicomponent metallic glasses, Chem. Mater., 20 (2008), 4548-4550, doi:10.1021/ cm8009644
${ }^{32}$ E. J. Kelly, The active iron electrode I. Iron dissolution and hydrogen evolution reactions in acidic sulfate solutions, J. Electrochem. Soc., 112 (1965), 124-131, doi:10.1149/1.2423480

${ }^{33}$ D. A. Stevens, J. R. Dahn, Electrochemical characterization of the active surface in carbon-supported platinum electrocatalysts for PEM fuel cells, J. Electrochem. Soc., 150 (2003), A770-A775, doi:10.1149/1.1573195

${ }^{34}$ Y. Z. Lu, Y. Y. Jiang, H. B. Wu, W. Chen, Nano-PtPd cubes on graphene exhibit enhanced activity and durability in methanol electrooxidation after CO stripping-cleaning, J. Phys. Chem. C, 117 (2013), 2926-2938, doi:10.1021/jp3116726

${ }^{35}$ Y. S. Li, F. R. Hao, Y. H. Wang, Y. H. Zhang, C.W. Ge, T. H. Lu, Facile synthesis of octahedral Pt-Pd nanoparticles stabilized by silsesquioxane for the electrooxidation of formic acid, Electrochim. Acta, 133 (2014), 302-307, doi:10.1016/j.electacta.2014.04.030

${ }^{36}$ Y. X. Chen, M. Heinen, Z. Jusys, R. J. Behm, Kinetics and mechanism of the electrooxidation of formic acid-spectroelectrochemical studies in a flow cell, Angew. Chem. Int. Ed., 45 (2006), 981-985, doi:10.1002/anie.200502172

${ }^{37}$ N. Cheng, H. F. Lv, W. W. Wang, S. C. Mu, M. Pan, F. Marken, An ambient aqueous synthesis for highly dispersed and active $\mathrm{Pd} / \mathrm{C}$ catalyst for formic acid electro-oxidation, J. Power Sources, 195 (2010), 7246-7249, doi:10.1016/j.jpowsour.2010.05.039

${ }^{38}$ R. P. Buck, L. R. Griffith, Voltammetric and chronopotentiometric study of the anodic oxidation of methanol, formaldehyde, and formic acid, J. Electrochem. Soc., 109 (1962), 1005-1013, doi:10.1149/ 1.2425226

${ }^{39} \mathrm{C}$. F. Melius, On the role of d electrons in chemisorption and catalysis on transition metal surfaces, Chem. Phys. Lett., 39 (1976), 287-290, doi:10.1016/0009-2614(76)80076-0

${ }^{40}$ M. H. Shao, K. Sasaki, R. R. Adzic, Pd-Fe nanoparticles as electrocatalysts for oxygen reduction, J. Am. Chem. Soc., 128 (2006), 3526-3527, doi:10.1021/ja060167d 